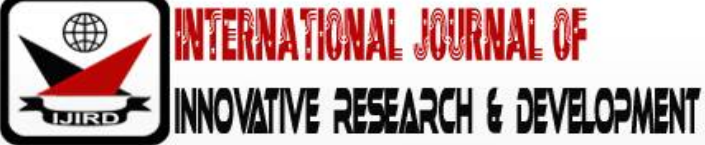

ISSN 2278 - 0211 (Online)

\section{Effects of Liquid Bio-Fertilizer and Poultry Manure on Soil Fertility and Performance of Okra (Abelmoschus Esculentus L) in Minna, Nigeria}

\author{
Nweke, R.N. \\ Postgraduate Student, Department of Soil Science and Land Management, \\ Federal University of Technology, Minna, Nigeria \\ Adeboye, M.K.A \\ Lecturer, Department of Soil Science and Land Management, \\ Federal University of Technology, Minna, Nigeria \\ Ozi, F.U \\ Research Assistant, Ebonyi State University, Nigeria
}

\begin{abstract}
:
The peasant vegetable farmers in Minna are faced with challenges associated with the use of imported chemical fertilizers, such as high cost, scarcity and short-lived effect of these fertilizers on soil fertility and crop improvement. These challenges have left the farmers with no other option than searching for alternative sources of improving the soil fertility and crop yields. A research was conducted in the Screen house of Federal University of Technology, Minna, to determine the initial and residual effects of liquid bio-fertilizer and poultry manure on some selected soil properties and yields of okra (Abelmoschus esculentus L). Surface Soil $(0-15 \mathrm{~cm})$ used for the experiment was collected from the University Teaching and Research Farm. Liquid bio-fertilizer was applied at rate of $100 \mathrm{l} \mathrm{ha}^{-1}, 200 \mathrm{l} \mathrm{ha}^{-1}$ and $300 \mathrm{l} \mathrm{ha}^{-1}$ and poultry manure at $3 \mathrm{t} \mathrm{ha-1,6} \mathrm{tha-1}$ and $9 \mathrm{t}$ ha $^{-1}$ and a control were fitted in a completely randomized design with four replications which gave a total of 28 pots. Data collected were analyzed using analysis of variance (ANOVA). Treatments means where significant were separated using the Duncan's Multiple Range Test at $5 \%$ level of probability. The result revealed the effectiveness of liquid bio fertilizer and poultry manure in improvement of soil organic carbon, total nitrogen, available phosphorus and overall yield of okra. Poultry manure applied at $9 \mathrm{t} \mathrm{ha}^{-1}$ produced the highest residual effects on the soil and was optimum for production of okra under screen house system.
\end{abstract}

Keywords: Liquid bio-fertilizer, poultry manure, soil fertility, okra yield, Minna, Nigeria

\section{Introduction}

Most arable soils of Nigeria are inherently low in fertility and incapable of supplying adequate nutrients for a favorable productivity of crops without supplementation from fertilizers (Bala, 2015). Shortage and high cost of inorganic fertilizers have also placed it out of reach of most peasant farmers, leaving them with no other option than to look for alternative sources of fertilization for crop improvement. Farmyard manure, crop residues and bio-fertilizer which are available in large quantities and affordable to peasant farmers can be a good alternative to inorganic fertilizers (Omisore et al., 2009). In 2003, it was funded that Nigeria generates about 932.5 metric tons of commercial poultry manure annually which are readily available and can be useful in agriculture (Adewumi et al., 2011).

Liquid bio-fertilizer is a form of bio-fertilizers while bio-fertilizers are products containing living cellsof different types of microorganisms which when, applied to plant or soil, colonize the plant (s) rhizosp here and promote growth by converting nutritionally important elements in soil such as nitrogen, phosphorus from unavailable to available-forms through biological process 'like nitrogen fixation and solubilization of phosphate (Rokhzadi et al., 2008). They are formulated from botanical extracts into liquids that are readily absorbed in soluble state and sometimes fortified with nutrient elements that promote healthy plants growth and development (Danbara and Green Planet, 2003).

Poultry manure is organic waste material from poultry farm consisting of droppings, poultry litters, left over feeds, remains of dead birds, shells and feathers. According to Zublena and Barker (1997), the nutrient composition of poultry manure varies with the type of bird, system of production, the feed ration, the proportion of litter to droppings, the manure handling system and the type of litter. Senjobi et al (2010) noted that poultry manures improved all the growth parameters of the leafy vegetables, including water-holding capacity and other soil physical properties (Adeleye et al., 2010).

Okra, (Abelmoschus esculentus L.), belongs to the family Malvaceae, originating from tropical and subtropical Africa (Inder et al., 2014).Okra cultivation and production has been wide spread and can be found in every market across 
Africa because of its economic and health values (Ngbede et al., 2014). Okra production worldwide is estimated at 6 million tons per hectare and 500,000-600,000 tons per year in West Africa (Ngbede et al., 2014). Its nutritional constituents include carbohydrate, protein, phosphorus, calcium, magnesium, iron, vitamin A and C with traces of vitamin B. It is primarily valued for its tender, immature green pods in fresh form; however, its curry, soups, stews and edible young leaves are also popular and is recommended for consumption by World Health Organization due to its ability to fight diseases (Inder et al., 2014). Okra has been found to be a rich source of vitamins A and C, calcium, thiamine and riboflavin, iron and is used as medicine in the treatment of peptic ulcer (Uka et al., 2013).

This study was conducted to determine: (i) The effects of liquid bio-fertilizer and poultry manure on soil organic carbon, nitrogen phosphorus, potassium and yield and yield components of okra. (ii) The residual effects of liquid biofertilizer and poultry manure on the above soil properties; yield and yield components of okra. (iii) The relationship between the above-named soil properties and yield and yield components of okra.

\section{Methodology}

\subsection{Study Location and Soil Collection Site}

The research was conducted in the Screen house of the Federal University of Technology, Minna, Nigeria. Surface Soil $(0-15 \mathrm{~cm})$ used was collected from the University Teaching and Research Farm. Geographic location of soil collection point is on latitude $09^{\circ} 31^{\prime} 18.2^{\prime \prime} \mathrm{N}$ and longitude $6^{\circ} 27^{\prime} 39.6^{\prime \prime} \mathrm{E}$ and elevation ranged from 229.5 to $250.4 \mathrm{~m}$ above sea level. Climate of Minna is sub-humid with mean annual rainfall of about $1284 \mathrm{~mm}$ and a distinct dry season of about 5 months duration occurring from November to March. Prior to the soil collection, the site has been cultivated with yam, sorghum and maize with little or no fertilizer application over the years.

\subsection{Source of Materials}

Liquid bio-fertilizer used for the experiment was purchased from Golden Neo-Life Diamite (GNLD)natural products distribution centre at Ibadan in Oyo State, Nigeria. Poultry manure sourced locally from Femilex Farm, a commercial deep litter system poultry farm in Kangiwa, Chanchaga, Minna West Council Area of Niger State, Nigeria.

\subsection{Treatments and Experimental Design}

The treatments were seven: three application rates of LBF- $100 \mathrm{l} \mathrm{ha-1,} 200 \mathrm{l} \mathrm{ha-1}$ and $300 \mathrm{l} \mathrm{ha-1}$; three application rates of PM- 3 t ha-1, $6 \mathrm{t} \mathrm{ha}^{-1} 9 \mathrm{t} \mathrm{ha}^{-1}$ and a control, arranged in a completely randomized design (CRD) with four replications which gave a total of 28 pots.

\subsection{Agronomical Practices}

The experiment was conducted using 15-litre plastic pots containing $10 \mathrm{~kg}$ of soil. The pots were perforated at the base to allow excess water to drain out. The top soil collected was sun dried, gently crushed and sieved through a $2 \mathrm{~mm}$ sieve to remove gravels and other particles and $10 \mathrm{~kg}$ soil weighed into each pot. The LBF was diluted at the ratio of $1 \mathrm{ml}$ to $1 \mathrm{l}$ of water as recommended by the LBF producer which is also similar to the dilution rate by Iraj et al, (2013). Poultry manure was sun dried to reduce the moisture content and manually crushed into smaller particle size to enhance interaction and aid the release of nutrients into the soil by the material.

The crop was planted 2 seeds per pot and later thinned to 1 per pot at 2 weeks after of sowing (WAS). Irrigation was carried out using watering cans during morning periods of everyday. The pots were watered to field capacity (half the volume of soil) while weeding was done as at when due by hand-pulling approach. Poultry manure was incorporated into the pots 1 week before sowing while LBF was applied using fertigation method two times; at 2 and 6 WAS.

\subsection{Soil Sampling and Analysis}

Surface soil $(0-15 \mathrm{~cm})$ samples were collected at eight points along four diagonal transects and bulked together to form four composite samples used for the experiment. Four soil samples were again collected from the bulked samples and labeled A, B, C and D for the initial characterization of the soil. At flowering stage and physiological maturity of the plant, soil samples were collected from each pot at four different depths during each experiment. The samples collected were air-dried, gently crushed and sieved with $2 \mathrm{~mm}$ opening to remove gravels, debris and determine some physical and chemical properties of the soil. The samples were also subjected to analysis using standard methods as described by Agbenin (1995). Briefly, particle size was determined by Bouyocous hydrometer method using sodium hexametaphosphate as dispersing agent (Gee and Or, 2002). The textural classes of the soils were then determined using IUSS soil Textural Triangle. Soil $\mathrm{pH}$ was determined in 1:2.5 soil to water and $\mathrm{CaCl}_{2}$ using a glass electrode $\mathrm{pH}$ meter.

Organic carbon was determined using Walkley-Black method (1945). Total nitrogen was determined by using the microKjeldhal method (Millerand Houghton, 1947). Available phosphorus extracted with the Bray P 1 method and P in extract determined using spectrophotometer after adding P developer re-agent and allowed the solution to build up P content. Determination of the exchangeable bases was done using ammonium acetate $\left(\mathrm{NH}_{4} \mathrm{OAc}\right)$ displacement method. Exchangeable $\mathrm{K}$ in the extract was determined by Flame Photometric method, while Ca and Mgwere by Na-EDTA titrimetric method while Na was determined using a Jenway PFP7 Flame Photometer (Harro et al., 1983).

\subsection{Yield and Yield Components Analysis}

The plant heights were recorded at 4, 6, 8 and 10 WAS by a metre rule from the ground level to tip of the base of the flag of leaf. This was repeated at 4 6, 8 and 10 WAS. Pod yields and fresh weight were also determined at physiological 
maturity. Number of pods produced in each pot was counted, harvested and weighed immediately after harvest to avoid loss of moisture content. The plant total biomass was also determined (the pots were watered, the plants uprooted, carefully labeled, weighed and recorded).

\subsection{Liquid Bio-Fertilizer and Poultry Manure Analysis}

Samples of the LBF and PM were collected and analysed for total N, available $\mathrm{P}$, and exchangeable $\mathrm{K}$ to determine their nutrients composition. They were analysed using the routine analysis as described by Tel (1984). Total N, by Kjeldahl approach and available P was determined colorimetrically after Bray-P1 extraction. Exchangeable K was extracted with 1N $\mathrm{NH}_{4} \mathrm{AOc}$ and determined using Flame Photometer and Atomic Absorption Spectrophotometer.

\subsection{Statistical Analysis}

Data collected were analyzed using analysis of variance (ANOVA). Treatments means where significant were separated using the Duncan's Multiple Range Test at $5 \%$ level of probability unless otherwise stated. Correlation analysis (Pearson method) was carried between the soil properties and yield and yield components of okra. Values obtained from the selected soil properties and okra parameters were compared using t-test. All computation was done using the General Linear procedure (GLM) of SAS (SAS, 2002).

\section{Results and Discussion}

\subsection{Physical and Chemical Properties of the Soil and Nutrient Composition of Poultry Manure and Liquid Bio-Fertilizer}

The analysis of the physical and chemical properties of the soil, nutrients composition of poultry manure and liquid bio-fertilizer used in the trials are shown Table 1. The soil had a loamy sand texture, with sand being the dominant particle (830 $\left.\mathrm{g} \mathrm{kg}^{-1}\right)$.The soil is slightly acidic (6.6); total $\mathrm{N}\left(1.96 \mathrm{~g} \mathrm{~kg}^{-1}\right)$ was moderate, but lowin essential nutrients particularly organic carbon level $\left(6.62 \mathrm{~g} \mathrm{~kg}^{-1}\right)$ and extractable P Bray1 $\left(6 \mathrm{mg} \mathrm{kg}^{-1}\right)$. The exchangeable bases $\left(\mathrm{cmol} \mathrm{kg}^{-1}\right)$ were $\mathrm{Ca}^{2+}(4.48), \mathrm{Mg}^{2+}(1.36)$ and $\mathrm{K}^{+}(0.13), \mathrm{Na}^{+}(0.62)$; whereas $\mathrm{K}^{+}$was low, exchangeable $\mathrm{Na}^{+}$and $\mathrm{Ca}^{2+}$ were medium while $\mathrm{Mg}^{2+}$ dominated the soil exchangeable bases. The value of the soil $\mathrm{pH}$ indicated that most nutrients will be available to crop roots; as most crops' nutrients are readily available at $6.6 \mathrm{pH}$ range (Adeboye et al., 2009). The organic carbon content of the soils was low. Jamala and Oke (2013) found that savanna soils are between the range of low to medium in organic carbon contents which can be attributed to rapid mineralization of organic matter, inadequate return of crop residues, poor arable crop management and land use practices prevalent in the area. The soils total $\mathrm{N}$ and available $\mathrm{P}$ were also low. The total $\mathrm{N}$ status and available $\mathrm{P}$ of the soils may be ascribed to low organic matter contents which is the major reservoir of soil $\mathrm{P}$ and $\mathrm{N}$ in the soil. Generally, the soil is suitable for producing most crops in the tropics.

Poultry manure had high total nitrogen and exchangeable potassium but moderate in phosphorus content. The relatively high content of nitrogen, phosphorus and potassium in poultry manure suggests that it is a good source of crop nutrients and improvement of soil fertility in terms of nitrogen, phosphorus and potassium. Mokwunye (2000), also confirmed that poultry manure contains high nutrients especially phosphorus which positively affected the growth and yields of vegetables crops. Robinson and Beauchamp (1982) reported that poultry manure produced the following percentage nutrients: nitrogen (65.5\%), phosphorus (68.5\%) and potassium $(83.5 \%)$.

The liquid bio-fertilizer nutrient contents were very low, especially in exchangeable K (Chude, 2011). This may be ascribed to the rate of active ingredients used by the producer during the formulation process. Moreover,the recommended dilution rate (1 millimeter to 1 litre) may also have contributed to such low nutrients content of the fertilizer.

\subsection{Initial and Residual Effects of Liquid Bio-Fertilizer and Poultry Manure on Plant Height at Different Growth Stages}

The response of okra height to initial and residual effect of liquid bio-fertilizer (LBF) and poultry manure (PM) at different growth stages is presented in Table 2 . The plant showed significant increase $(P<0.05)$ in height from 4 weeks after sowing (WAS) to 10 WAS of the trial. However, their residual effects on height were significant at 4 and 6 WAS only. The pots which received $9 \mathrm{t} \mathrm{ha}^{-1} \mathrm{PM}$ treatment recorded and maintained the tallest okra all through the growth stages of the plant while the control pots produced the shortest plants both in initial and residual effects of the trial. The height of okra produced by application of $9 \mathrm{t} \mathrm{ha}^{-1} \mathrm{PM}$ in the initial trial were taller than the control plants by 7-34.8 \% between 6 and 10 WAS. The residual effects of the treatment on height were also 47 and $50 \%$ more than the control at 4 and 6 WAS respectively under the same application of treatment.

The increase in the vegetative growth of okra by the application of poultry manure might be due to its role in enhancing soil physical and chemical properties especially, water holding capacity and aeration resulting in more nutrients and moisture being made available for enhancement of plant growth. These results are in agreement with Ayeni et al. (2010) and Senjobi et al (2010) who reported that poultry manure enhances basic soil physical properties which in turn increased all growth parameters of leafy vegetable. Onwu et al (2002) also obtained high yield of okra after application of poultry manure. The relatively poor performance of liquid bio-fertilizer disagrees with the report of Uka et al., (2013) who observed that liquid bio-fertilizer significantly improved nitrogen content of the soil which eventually resulted in a vigorous growth of okra. Enujeke and Ojeifo (2013) also found that the yield of plants that received 1501itres ha $^{-1}$ of liquid bio-fertilizer was highest; followed by plants that received $251 \mathrm{l} \mathrm{ha}^{-1}$. The residual effect observed in both trials, particularly at highest rate of poultry manure application implies that the release of nutrients into the soil by poultry manure is gradual and long lasting. Abou, et al. (2005) also found that nutrients contained in poultry manures are released more slowly ensuring longer residual effects, improved root development and higher crop yields. 


\begin{tabular}{|c|c|c|c|}
\hline Parameters & Soil Value & Poultry Manure & Liquid Bio-Fertilizer \\
\hline Sand $\left(\mathrm{g} \mathrm{kg}^{-1}\right)$ & 830 & - & - \\
\hline Silt $\left(\mathrm{g} \mathrm{kg}^{-1}\right)$ & 63 & - & - \\
\hline Clay $\left(\mathrm{g} \mathrm{kg}^{-1}\right)$ & 108 & - & - \\
\hline Textural class & Loamy sand & - & - \\
\hline $\mathrm{pH}\left(\mathrm{H}_{2} \mathrm{O}\right)$ & 6.60 & - & - \\
\hline $\mathrm{pH}\left(\mathrm{CaCl}_{2}\right)$ & 5.55 & - & - \\
\hline Organic matter $\left(\mathrm{g} \mathrm{kg}^{-1}\right)$ & 6.62 & - & $0.0560 \%$ \\
\hline Total N $\left(\mathrm{g} \mathrm{kg}^{-1}\right)$ & 1.92 & $0.920 \%$ & $0.0026 \%$ \\
\hline Available P $\left(\mathrm{mg} \mathrm{kg}^{-1}\right)$ & 6.00 & $0.050 \%$ & $0.0002 \%$ \\
\hline Exchangeable K $\left(\mathrm{cmol} \mathrm{kg}^{-1}\right)$ & 0.13 & $0.065 \%$ & - \\
\hline Na $\left(\mathrm{cmol} \mathrm{kg}^{-1}\right)$ & 0.17 & - & - \\
\hline $\mathrm{Ca}\left(\mathrm{cmol} \mathrm{kg}^{-1}\right)$ & 4.48 & - & - \\
\hline $\mathrm{Mg}\left(\mathrm{cmol} \mathrm{kg}^{-1}\right)$ & 1.36 & - & - \\
\hline Exchange acidity $\left(\mathrm{cmol} \mathrm{kg}^{-1}\right)$ & 0.62 & - & \\
\hline
\end{tabular}

Table 1: Physical and Chemical Properties of the Soil and Nutrients Composition of Liquid Bio-Fertilizer and Poultry Manure Used in the Trials

\subsection{Initial and Residual Affects of Liquid Bio-Fertilizer and Poultry Manure and on pod and biomass Yields}

The treatments had significant effects $(\mathrm{P}<0.05)$ on both weight of pods and plant biomass during the initial trial. However, only the biomass yield was significantly affected by the treatment during the residual trial (Table 3). With exception of number of pods, $9 \mathrm{t} \mathrm{ha}^{-1} \mathrm{PM}$ treatment recorded the highest pods weight and plant biomass which was significantly higher than the rest statistically. The control pots gave the lowest weight of pods. The differences in number of pods, weight of pods and plant biomass yields between the initial and residual trials are shown in Table4. Generally, there was no significant difference between the initial and their residual effects on number of pods and biomass yield of the plant.

Poultry manure promoted weight of pods and plant biomass yields which were significantly different in the initial and residual trials. This positive effect on the plant may be due to relatively high content of $\mathrm{N}, \mathrm{P}$ and $\mathrm{K}$ in poultry manure as found byAkande et al., (2010). This agrees with the study of John et al. (2004) who reported that poultry manure contains essential nutrients which are associated with high photosynthetic activities that promote root and vigorous vegetable growth of plants. Appropriate application of poultry manure could possibly sustain okra production under green agriculture in the tropics (Dauda et al., 2008). The lack of residual effects of the treatment on the individual yield components of the plant, but rather reflected on the biomass only, may be due to pull-effects; since the biomass measured the entirety of the plant and this suggests that in measuring residual effect of liquid bio-fertilizer or poultry manure on okra, every part of the plant may be considered. The use of poultry manure as soil amendments to sustain crop yields has been found effective for vegetable crops in Nigeria by Adeleye, et al (2010).

There was no significant difference in the initial and final yields of pods and plant biomass. The implication of these results is that residual nutrients released into the soil from the treatments sustained the plant during second cropping without application of the treatments again. This agrees with the findings of Omotoso and Johnson (2015) who reported that manure when efficiently and effectively applied, ensures sustainable crop productivity by immobilizing nutrients that are susceptible to leaching. Monroe et al. (2004) also observed long-term residual benefits of poultry manure from yield obtained and higher phosphorus buildup of the soil. Result also points to the fact that the use of organic fertilizer could be cheaper means of soil fertility improvement on a sustainability basis.

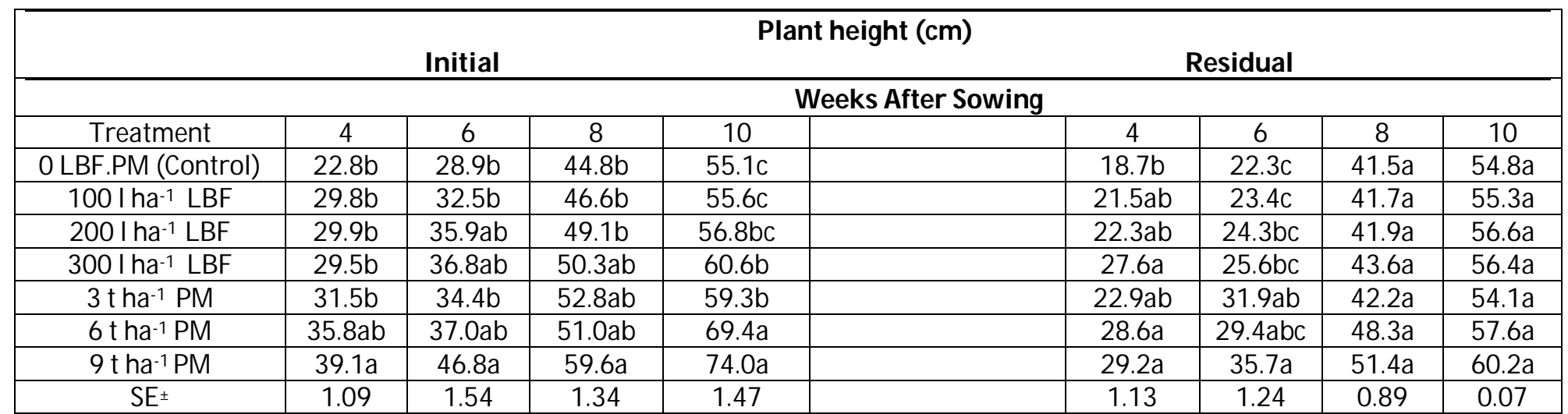

Table 2: Initial and Residual Affects of Liquid Bio-Fertilizer and Poultry Manure on Plant Height at Different Growth Stages

Mean Followed by the Same Letter (S) in a Treatment Column Are Not Significantly Different at P $<0.05$

LBF - Liquid Bio-Fertilizer

PM - Poultry Manure 


\begin{tabular}{|c|c|c|c|c|c|c|}
\hline \multicolumn{5}{|c|}{ Initial } & \multicolumn{2}{|c|}{ Residual } \\
\hline Treatment & $\begin{array}{l}\text { No of pods } \\
\text { per plant }\end{array}$ & $\begin{array}{l}\text { Weight of } \\
\text { pods } \\
\left.\text { (g plant }{ }^{-1}\right)\end{array}$ & $\begin{array}{c}\text { Biomass yield } \\
\left.\text { (g plant }{ }^{-1}\right)\end{array}$ & $\begin{array}{c}\text { No of pods } \\
\text { per plant }\end{array}$ & $\begin{array}{l}\text { Weight of pods } \\
\left.\text { (g plant }{ }^{-1}\right)\end{array}$ & $\begin{array}{c}\text { Biomass yield } \\
\left.\text { (g plant }{ }^{-1}\right)\end{array}$ \\
\hline $\begin{array}{l}0 \text { LBF.PM } \\
\text { (Control) }\end{array}$ & $1 \mathrm{a}$ & $20.50 \mathrm{~b}$ & $61.67 \mathrm{c}$ & $1 \mathrm{a}$ & $20.07 a$ & $52.26 \mathrm{c}$ \\
\hline 100 l ha-1 $^{-1} \mathrm{LBF}$ & $1 \mathrm{a}$ & $23.13 \mathrm{~b}$ & $61.44 \mathrm{c}$ & $1 \mathrm{a}$ & $22.11 \mathrm{a}$ & $54.67 \mathrm{c}$ \\
\hline 200 l ha-1 LBF $^{-1}$ & $1 \mathrm{a}$ & $28.74 b$ & $63.58 \mathrm{bc}$ & $1 \mathrm{a}$ & $28.40 \mathrm{a}$ & $58.18 \mathrm{bc}$ \\
\hline $300 \mathrm{l} \mathrm{ha}^{-1} \mathrm{LBF}$ & $2 a$ & $33.81 \mathrm{ab}$ & $67.87 \mathrm{bc}$ & $1 \mathrm{a}$ & $32.34 a$ & $61.89 \mathrm{bc}$ \\
\hline 3 tha- $^{-1} \mathrm{PM}$ & $1 \mathrm{a}$ & $32.40 \mathrm{~b}$ & $66.58 \mathrm{bc}$ & $1 \mathrm{a}$ & $31.84 a$ & $65.03 \mathrm{bc}$ \\
\hline 6 t ha- $^{-1} \mathrm{PM}$ & $2 \mathrm{a}$ & $36.06 \mathrm{~b}$ & $77.93 \mathrm{~b}$ & $2 \mathrm{a}$ & $34.53 \mathrm{a}$ & $69.18 \mathrm{~b}$ \\
\hline 9 t ha- $^{-1} \mathrm{PM}$ & $2 a$ & $52.06 a$ & 93.71a & $2 a$ & $42.01 \mathrm{a}$ & $82.49 a$ \\
\hline $\mathrm{SE}^{ \pm}$ & 0.08 & 3.01 & 2.59 & 0.09 & 2.93 & 2.35 \\
\hline
\end{tabular}

Table 3: Initial and Residual Effects of Liquid Bio-Fertilizer and Poultry Manure on Pods and Biomass Yields Mean Followed by the Same Letter (S) in a Treatment Column Are Not Significantly Different at $\mathrm{P}<0.05$ LBF - Liquid Bio-Fertilizer PM - Poultry Manure

\begin{tabular}{|c|c|c|c|c|c|c|c|c|c|}
\hline \multirow{2}{*}{ Treatments } & \multicolumn{3}{|c|}{ No of Pods Per Pant } & \multicolumn{3}{c|}{ Weight of Pods (g) } & \multicolumn{3}{c|}{ Biomass Yield (g) } \\
\cline { 2 - 10 } & Initial & Residual & SE \pm & Initial & Residual & SE \pm & Initial & Residual & SE \pm \\
\hline 0 LBF PM (Control) & 1 & 1 & NS & 20.50 & 20.07 & NS & 61.67 & 52.26 & NS \\
\hline 100 l LBF ha-1 & 1 & 1 & NS & 23.13 & 22.11 & NS & 61.44 & 54.67 & NS \\
\hline 200 l LBF ha-1 & 1 & 1 & NS & 28.74 & 28.40 & NS & 63.58 & 58.18 & NS \\
\hline 300 lBF ha-1 & 2 & 1 & NS & 33.81 & 32.34 & NS & 67.87 & 61.89 & NS \\
\hline 3 t PM ha $^{-1}$ & 1 & 1 & NS & 32.40 & 31.84 & NS & 66.69 & 65.03 & NS \\
\hline 6 t PM ha $^{-1}$ & 2 & 2 & NS & 36.06 & 34.53 & NS & 77.96 & 69.18 & NS \\
\hline 9 t PM ha $^{-1}$ & 2 & 2 & NS & 52.06 & 42.01 & NS & 93.71 & 82.49 & NS \\
\hline
\end{tabular}

Table 4: Comparison of the Initial and Residual Effects of Liquid Bio-Fertilizer and Poultry Manure on Okra Yields NS-Not Significant at $\mathrm{P}<0.05$

$\mathrm{LBF}=$ Liquid Bio-Fertilizer

$\mathrm{PM}=$ Poultry Manure

3.5. Initial and Residual Effects of Liquid Bio-Fertilizer and Poultry Manure on Some Selected Soil Properties.

Table 5 presents the initial and residual effects of liquid bio-fertilizer and poultry manure on some selected soil properties. The outcomes of both trials (initial and residual) were similar. However, significant differences were found among the values of organic carbon, total $\mathrm{N}$, and available P. Poultry manure applied at $9 \mathrm{t} \mathrm{ha}^{-1}$ also gave the highest values of soil organic carbon compared to rest of the treatments. The value of organic carbon obtained from the initial and residual trials were higher than the control by 41 and 38\% respectively.

The result also shows that LBF-total $\mathrm{N}$ and PM-total $\mathrm{N}$ contents of the soils increased with increase in rate of application of these treatments. However, the values of exchangeable K were not affected by the treatment. Table 6 shows the comparison of the initial and residual effects of liquid bio-fertilizer and poultry manure onthe values of soil organic carbon, total N, available P and exchangeable K. There was significant difference at treatment $300 \mathrm{l} \mathrm{LBF}$ ha-1 in the values of total $\mathrm{N}$ while the rest of the treatments were not significantly different in the contents of the above-mentioned soil properties.

Both the poultry manure and liquid bio-fertilizer improved the soil organic carbon, total N, available P, but exchangeable $\mathrm{K}$ was not. There were significant differences in the values of soil properties studied except exchangeable $\mathrm{K}$. The residual effects showed the potentials of poultry manure to release nutrients into the soil on a long-term basis. The result is supported by Makinde and Ayoola, 2008and Bayu et al., 2006, who stated that manures are usually applied at higher rates relative to inorganic fertilizers and when applied at higher rates, they give residual effects on the growth and yield of succeeding crops. Nutrients contained in poultry manures are released more slowly ensuring longer residual effects, improved root development and higher crop yields (Abou et al., 2005). 


\begin{tabular}{|c|c|c|c|c|c|c|c|c|}
\hline & \multicolumn{4}{|c|}{ Initial } & & \multicolumn{3}{|c|}{ Residual } \\
\hline \multirow[t]{2}{*}{ Treatment } & \multirow{2}{*}{$\begin{array}{c}\mathrm{OC} \\
\left(\mathrm{g} \mathrm{kg}^{-1}\right)\end{array}$} & \multirow{2}{*}{$\begin{array}{c}\mathrm{T} \mathrm{N} \\
\left(\mathrm{g} \mathrm{kg}^{-1}\right)\end{array}$} & \multirow{2}{*}{$\frac{\text { Avail. P }}{\left(\mathrm{mg} \mathrm{kg}^{-1}\right)}$} & \multirow{2}{*}{$\begin{array}{c}\text { Exch. K } \\
\left(\mathrm{cmol} \mathrm{kg}^{-1}\right)\end{array}$} & \multirow{2}{*}{$\begin{array}{c}\mathrm{OC} \\
\left(\mathrm{g} \mathrm{kg}^{-1}\right)\end{array}$} & \multirow{2}{*}{$\begin{array}{c}\mathrm{T} \mathrm{N} \\
\left(\mathrm{g} \mathrm{kg}^{-1}\right)\end{array}$} & Avail. P & \multirow{2}{*}{$\begin{array}{c}\text { Exch. K } \\
\left(\mathrm{cmol} \mathrm{kg}^{-1}\right)\end{array}$} \\
\hline & & & & & & & $\left(\mathrm{mg} \mathrm{kg}^{-1}\right)$ & \\
\hline $\begin{array}{l}\text { 0 LBF.PM } \\
\text { (Control) }\end{array}$ & $3.90 \mathrm{~d}$ & $2.16 \mathrm{c}$ & $14 \mathrm{c}$ & $0.16 \mathrm{a}$ & $3.27 d$ & $1.75 \mathrm{~b}$ & $14 \mathrm{~b}$ & $0.11 \mathrm{a}$ \\
\hline 100 Lha $^{-1}$ LBF & $5.45 \mathrm{c}$ & $2.49 \mathrm{bc}$ & $17 \mathrm{bc}$ & $0.19 \mathrm{a}$ & $4.20 \mathrm{c}$ & $1.96 \mathrm{~b}$ & $15 \mathrm{~b}$ & $0.17 \mathrm{a}$ \\
\hline 200 Lha $^{-1}$ LBF & $5.081 \mathrm{bc}$ & $2.51 \mathrm{bc}$ & $17 \mathrm{bc}$ & $0.19 \mathrm{a}$ & $4.50 \mathrm{c}$ & $1.98 \mathrm{~b}$ & $16 \mathrm{~b}$ & $0.16 \mathrm{a}$ \\
\hline 300 Lha-1 $^{-1}$ LBF & $6.05 \mathrm{bc}$ & $2.68 \mathrm{bc}$ & $17 \mathrm{bc}$ & $0.20 \mathrm{a}$ & $4.94 \mathrm{c}$ & $1.90 \mathrm{~b}$ & $16 \mathrm{~b}$ & $0.16 a$ \\
\hline 3 t ha-1 $^{-1} \mathrm{PM}$ & $6.59 \mathrm{abc}$ & $2.71 \mathrm{bc}$ & $15 b c$ & $0.20 \mathrm{a}$ & $6.07 \mathrm{~b}$ & $2.19 \mathrm{~b}$ & $15 \mathrm{~b}$ & $0.17 \mathrm{a}$ \\
\hline 6 t ha $^{-1} \mathrm{PM}$ & 6.89ab & $3.43 a b$ & $19 \mathrm{~b}$ & $0.24 a$ & $5.94 \mathrm{~b}$ & $2.50 \mathrm{~b}$ & $18 a$ & $0.17 \mathrm{a}$ \\
\hline 9 t ha-1 $^{-1} \mathrm{PM}$ & $7.45 a$ & $4.16 \mathrm{a}$ & $22 \mathrm{a}$ & $0.24 \mathrm{a}$ & $7.28 \mathrm{a}$ & $3.93 a$ & $20 a$ & $0.18 \mathrm{a}$ \\
\hline
\end{tabular}

Table 5: Effects of Liquid Bio-Fertilizer and Poultry Manure and Their Residual Effects on Some Selected Soil Properties Mean Followed by the Same Letter (S) in a Treatment Column Are Not Significantly Different at $\mathrm{P}<0.05$ $\mathrm{LBF}=$ Liquid Bio-Fertilizer $\mathrm{PM}=$ Poultry Manure

\subsection{Correlation Matrix between Some Selected Soil Properties and Yields of Okra}

The correlation matrix between the values of organic carbon, total $\mathrm{N}$, available $\mathrm{P}$, exchangeable $\mathrm{K}$ and yields of okra are shown in Table 7. Organic carbon significantly $(\mathrm{P}<0.01$ ) correlated with total N, available $\mathrm{P}$, exchangeable $\mathrm{K}$, weight of pods and plant biomass. Similarly, total $\mathrm{N}$ correlated significantly with available $\mathrm{P}$, exchangeable $\mathrm{K}$, weight of pods and plant biomass, while there was no significant relationship with number of pods. This was also found in the relationship between available $\mathrm{P}$ with weight of pods and plant biomass.

The significant relationship between organic carbon, total $\mathrm{N}$, available $\mathrm{P}$, exchangeable $\mathrm{K}$, plant biomass and weight of pods showed that the studied soil properties are required in production of okra. Mbah and Onweremadu (2009) found that essential nutrients such as nitrogen, phosphorus and potassium remain fundamental soil requirement for vegetable growth in the tropics. The increased yields in weight of pods and plant biomass as a result of increase in the rate of application of liquid bio-fertilizer and particularly poultry manure demonstrate the effectiveness of the treatments and the fact that continual increase of the treatments to a reasonable rate will lead to more yield of okra. These findingsagree with Tran et al, 2004), who stated that among the available means to achieve soil fertility and sustainability in agricultural production in the tropics, organic manure and bio-fertilizer in combination play important roles in soil nutrient improvement.

\begin{tabular}{|c|c|c|c|c|c|c|c|c|c|c|c|c|}
\hline \multirow[t]{2}{*}{ Treatments } & \multicolumn{3}{|c|}{ Organic Carbon $\left(\mathrm{g} \mathrm{kg}^{-1}\right)$} & \multicolumn{3}{|c|}{ Total N ( $\left.\mathrm{g} \mathrm{kg}^{-1}\right)$} & \multicolumn{3}{|c|}{ Avail. P (mg kg-1) } & \multicolumn{3}{|c|}{ Exch. K (cmol kg-1) } \\
\hline & Initial & $\begin{array}{l}\text { Residu } \\
\text { al }\end{array}$ & $\mathrm{SE} \pm$ & $\begin{array}{c}\text { Initia } \\
1\end{array}$ & Residua & $\mathrm{SE} \pm$ & $\begin{array}{c}\text { Initia } \\
\text { l }\end{array}$ & $\begin{array}{l}\text { Residu } \\
\text { al }\end{array}$ & $\mathrm{SE} \pm$ & $\begin{array}{c}\text { Initia } \\
\text { l }\end{array}$ & $\begin{array}{l}\text { Residu } \\
\text { al }\end{array}$ & $\mathrm{SE} \pm$ \\
\hline $\begin{array}{l}0 \text { LBF PM } \\
\text { (Control) }\end{array}$ & 3.90 & 3.27 & NS & 2.16 & 1.75 & NS & 14 & 14 & NS & 0.16 & 0.11 & NS \\
\hline $100 \mathrm{LBF}^{\text {h ha-1 }}$ & 5.45 & 4.20 & NS & 2.49 & 1.96 & NS & 17 & 15 & NS & 0.19 & 0.17 & NS \\
\hline 200 LBFl ha-11 & 5.081 & 4.50 & NS & 2.51 & 1.98 & NS & 17 & 16 & NS & 0.19 & 0.16 & NS \\
\hline $300 \mathrm{LBF}$ l ha-1 & 6.05 & 4.94 & NS & 2.68 & 1.90 & NS & 17 & 16 & NS & 0.20 & 0.16 & NS \\
\hline 3 t PM ha-1 $^{-1}$ & 6.59 & 6.07 & NS & 2.71 & 2.19 & NS & 15 & 15 & NS & 0.20 & 0.17 & NS \\
\hline 6 t PM ha- $^{-1}$ & 6.89 & 5.94 & NS & 3.43 & 2.50 & NS & 19 & 18 & NS & 0.24 & 0.17 & NS \\
\hline 9 t PM ha-1 $^{-1}$ & 7.45 & 7.28 & NS & 4.16 & 3.93 & NS & 22 & 20 & NS & 0.24 & 0.18 & NS \\
\hline
\end{tabular}

Table 6: Comparison of the Effects of Liquid Bio-Fertilizer and Poultry Manure on Some Selected Soil Properties

NS - Not Significantat $\mathrm{P}<0.05$

LBF=Liquid Bio-Fertilizer

$\mathrm{PM}=$ Poultry Manure 


\begin{tabular}{|c|c|c|c|c|c|c|c|}
\hline & $\begin{array}{c}\text { Organic } \\
\text { Carbon }\end{array}$ & Total N & Avail. P & Exch. K & $\begin{array}{c}\text { No Of } \\
\text { Pods }\end{array}$ & $\begin{array}{c}\text { Weight Of } \\
\text { Pods }\end{array}$ & $\begin{array}{c}\text { Plant } \\
\text { Biomass }\end{array}$ \\
\hline Organic carbon & 1 & & & & & & \\
\hline Total N & $0.538^{* *}$ & 1 & & & & & \\
\hline Avail. P & $0.589^{* *}$ & $0.485^{* *}$ & 1 & & & & \\
\hline Exch. K & $0.361^{* *}$ & $0.348^{* *}$ & $0.204 \mathrm{NS}$ & 1 & & & \\
\hline No of pods & $0.242 \mathrm{NS}$ & $0.211 \mathrm{NS}$ & $0.245 \mathrm{NS}$ & $0.108 \mathrm{NS}$ & 1 & & \\
\hline Weight of pods & $0.321^{*}$ & $0.136^{*}$ & $0.440^{* *}$ & $-0.013 \mathrm{NS}$ & $0.591^{* *}$ & 1 & \\
\hline Plant biomass & $0.447^{* *}$ & $0.457^{* *}$ & $0.486^{* *}$ & $0.042 \mathrm{NS}$ & $0.294^{*}$ & $0.629^{* *}$ & 1 \\
\hline
\end{tabular}

Table 7: Correlation Matrix between Some Selected Soil Properties and Yields Of Okra

\section{Conclusion and Recommendation}

Application of bio-fertilizer and poultry manure improved the following soil nutrients content: organic carbon, total $\mathrm{N}$ and available $\mathrm{P}$. The growth and yields of okra, especially height and biomass yields were greatly improved when fertilized with poultry manure at the rate of $9 \mathrm{t} \mathrm{ha}^{-1}$. The same rate of application produced the highest residual effects on soil nutrients content and overall yield of okra. Application of poultry manure at the rate of $9 \mathrm{t} \mathrm{ha}^{-1} \mathrm{was}_{\mathrm{s}}$ optimum and effective for production of okra under Screen house system in Minna. This study, therefore, suggest that vegetable farmers adopt application of poultry manure at the rate of $9 \mathrm{t} \mathrm{ha}^{-1}$ forsoil nutrients improvement, long lasting effect on the soil sand optimum yield of vegetable crops.

\section{References}

i. Abou, El. M, Hoda, M. M., Mohammed, A. and Fawzy, Z. F. (2005). Relationship, growth and yield of brocooli with increasing N, P or K in a mixture of NPK fertilizers. Annals Agriculture Science Moshtohon 43 (2), 791-805.

ii. Adeboye, M. K. A., Osunde, A. O., Ezenwa, M. I. S., Odofin, A. J. and Bala, A. (2009). Evaluation of the fertility status and suitability of some soils of arable cropping in the southern guinea savanna of Nigeria. Nig.J. Soil Sci.19(2): 115 $-120$

iii. Adeleye, E.O., Ayeni, L.S. and Ojeniyi, S.O. (2010). Effect of poultry manure on soil physico chemical properties, leaf nutrient contents and yield of yam (Dioscorea rotundata) on Alfisol in Southwestern Nigeria. Journal of American Science, 6 (10), 871-878.

iv. Adewumi, A.A., Adewumi, I.K. and Olaleye, V.F. (2011). Livestock waste menace: Fish wealth-solution. African Journal of Environmental Science Technology, 5, 149-154.

v. Agbenin, O.J. (1995). Laboratory Manual for soil and plant analysis. (Selected method and data analysis). Published by the author. Pp;140.

vi. Bala, A. (2015). Legumes and rhizobia: One of the nature's partnerships for food nutrition security of the poor. Federal University of Minna, Inaugural Lecture Series 33. 63 pp.

vii. Bayu, W., Rethman, N.F.G., Hammers, P.S. and Alemu, G. (2006). Effects of farmyard manure and inorganic fertilizers on sorghum growth, yield and Nitrogen use in a semi-arid area of Ethiopia. Journal of plant Nutrition, 29,391-407.

viii. Danbara, A. K. and Green Planet International (2003). Evaluation of Power plant TM liquid fertilizer for potato production in Plateau State, Nigeria. National Root Crop Research Institute, Jos. pp: 1-4.

ix. Dauda, S.N. Ajayi, F.A., and Ndor, E. (2008). Growth and yield of water melon (Citrullus lanatus) as affected by poultry manure application. Journal of Agriculture and Social Science, 4, 121-124.

x. Enujeke, E. C. and Ojeifo, I. M. (2013). Effects of Liquid Organic Fertilizer on Time of Tasselling, Time of Silking and Grain Yield of Maize (Zea mays). Publisher: Asian Economic and Social Society.Asian Journal of Agriculture and Rural Development, 3(4), 186-192.

xi. Harron W.R.A., Webster G. R., Cairns R, R. (1983). Relationships Between Exchangeable Sodium and Sodium Adsorption Ratio in a Solonetzic Soil Association. Can. J. Soil Sci. 63: 461-467

xii. Inder, J.S., Samnotra, R.K., and Kumar, V. (2014). Influence of bio-fertilizer application methods and inorganic Fertilizers on growth, seed yield and economics cost of okra (abelmoschus esculentus) under sub-tropical Irrigated area of Jammu. International Journal of Agricultural Sciences,10, 322-328.

xiii. Iraj, D., Khodabakhsh, P. K, and Ghazanfar, M. (2013). Effect of effective microorganisms activate on growth, yield and yield components of corn in Firozabad region. Agronomy Department, Yasouj Branch, Islamic Azad University, Yasouj, Iran. Annals of Biological Research, 4 (4),126-129.

xiv. Jamala, G. Y. and Oke, D. O. (2013). Soil organic carbon fractions as affected by land use in the Sourthern Guinea Savanna ecosystem of Adamawa State, Nigeria. Journal of Soil Science and Environmental Management, 4 (6), 116-12

xv. Makinde E.A and Ayoola A. A. (2008). Residual influence of early season crop fertilization and cropping system on growth and yield of cassava. American Journal of Agriculture and Biological Science. 3(4), 712-715.

xvi. Mbah, C.N. and Onweremadu ,E.U. (2009). Effect of Organic and Mineral Fertilizer Inputs on Soil and maize grain yield in an acid Ultisol in Abakaliki-South Eastern Nigeria; American-Eurasian Journal of Agronomy 2 (1), 07-12.

xvii. Mokwunye, U. (2000). Meeting the phosphorus needs of the soils and crops of West Africa: The Role of Indigenous Phosphate rocks. Paper presented on Balanced Nutrition Management systems for the Moist Savanna and Humid Forest Zones of Africa at a symposium organized by IITA at Ku Leuva at Cotonun, Benin Republic, October 9-12. 
xviii. Monroe, R., George, K., Lloyd, M. and Frank, S. (2004). Update on poultry litter as a nitrogen source and the longterm benefits of its use. University of Kentucky, Soil Science News and Views, 24 (1).

xix. Ngbede, S.O., Ibekwe, H.N., Okpara, S.C., Onyegbule, U.N. and Adejumo, L. (2014) An overview of okra production, processing, marketing utilization and constrains in Ayaragu in Ivo local government Area of Ebonyi State, Nigeria. Greener Journal of Agricultural Science, 4 (4),136-143.

xx. Omisore, J. K., Kasali, M.Y., and Chukwu, U. C. (2009). Determination of optimum poultry manure rate for maize production. Proceeding of the 43rd Annual Conference of Agricultural Society of Nigeria.

xxi. Omotoso, S. O. and Johnson, O. Y. (2015). Growth and Yield of Two Varieties of Okra (Abelmoschus esculentus (L). Moench) as affected by Potassium Fertilizer Sources Journal of Biology, Agriculture and Healthcare www.iiste.org (Online) 5, 8.

xxii. Onwu, A. C., Abubakar, J. R. and Unah, P. O. (2002). Effect of poultry manure on growth, yield of Okra and soil properties in Makurdi, North Central Nigeria. Universal Research Publications. International Journal of Agricultural and Food Science. Available online at http:/ / www. urpjournals.com

xxiii. Robinson, J. and Beauchamp, E. (1982). The Resource conservation Ethic Applied to Manure Management. In: The Manure Management Handbook, Ontario soil and crop Improvement Association, Ontario Ministry of Agriculture and Food, Ontario Agricultural College, Canada, pp: 1-2.

xxiv. Rokhzadi, A., Asgharzadeh, A., Darvish, F., Nourmohammadi, G. and Majidi, E. (2008). Influence of plant growthpromoting rhizobacteria on dry matter accumulation and yield of chickpea (Cicerarietinum L.) under field condition. American Eurasian Journal of Agriculture and Environmental Science, 3(2), 253257.

xxv. SAS (2003).SAS user's guide; statistical Cary N.C. statistical Analysis System Institute Inc. software version 9.1

xxvi. Senjobi, B. A., Peluola, C. O., Senjobi, C. T., Lawal, I. O., Ande, O.T. and Salami, B. T. (2010). Performance of Cochorus olitorius as influenced by soil type and organic manure amendments in Yewa North Local Government Area, Ogun State. African Journal of Biotechnology. 9 (33), 5309-5312.

xxvii. Stefan, T. (2003). Organic Agriculture: Sustainability market policies. CAB Organization for Economic Cooperation and Development, Pp: 95.

xxviii. Tel, D.A. and Hagarty, M. (1984). Soil and plant analysis. IITA Ibadan/ University of Guelph, Ontario, Canada, Pp: 277.

xxix. Tran, T.N.S, Vu, V.T., Luu, H.M., Kobayashi, H. and Omonrice, R. (2004). Effect of effective microorganisms activate (EMa) on growth and yield and yield components of corn. Annals biological research, 12,45-51

xxx. Uka, U.N., Chukwuka, K.S. and Iwuagwu, M. (2013). Relative Effect Of Organic And Inorganic Fertilizers On The Growth Of Okra (Abelmoschus esculentus ,L.). Journal of Agricultural Sciences, 58 (3), 159-166.

xxxi. Uka, U.N., Chukwuka, K.S. and Iwuagwu, M. (2013). Relative Effect of Organic and Inorganic Fertilizers on The Growth of Okra (Abelmoschus esculentus, L.). Journal of Agricultural Sciences, 58 (3), 159-166.

xxxii. Walkley, A. (1947). A Critical Examination of a Rapid Method for Determination of Organic Carbon in Soils - Effect of Variations in Digestion Conditions and of Inorganic Soil Constituents. Soil Science 63:251-257.

xxxiii. Zublena, J. P. and Barker, J. C. (1997). Poultry Manure as a Fertilizer Source Published by: North Carolina Cooperative Extension Service. Soil facts, fact sheet AG 439-5, Authored by J.P. Zublena 